(c) American Dairy Science Association, 2006.

\title{
Major Technological Advances and Trends in Cheese
}

\author{
M. E. Johnson ${ }^{1}$ and J. A. Lucey \\ University of Wisconsin, Center for Dairy Research, Madison 53706
}

\begin{abstract}
Over the last $25 \mathrm{yr}$, cheese production in the United States has more than doubled with most of the increase due to production in the western states. Processing large volumes of milk into cheese has necessitated changes in vat size and design, reliance on computer software, and milk standardization, including use of membrane concentration of milk either at the cheese plant or on the farm. There has been increased interest in specialty cheeses including cheese made from sheep, goat, and organic milks. In addition, membrane processing of whey into various value-added components has become routine. Changes in cheese manufacturing protocols have resulted in a reduction of the manufacturing time and the necessity for consistent and reliable starter activity. Major advances in the genetics of microorganisms have not only resulted in widespread use of fermentation-produced chymosin but also in starter bacteria with improved resistance to bacteriophage infection. Genomics and proteomics have increased the likelihood of the development of nonstarter adjuncts with specific enzymatic activity. Indeed, the use of adjunct microorganisms to produce cheese with a unique flavor profile or to produce cheese with more consistent or better quality flavor has gained almost universal acceptance.
\end{abstract}

Key words: cheese, technology, trend

\section{INTRODUCTION}

In the United States during the last 25 yr there has been a continued increase in both milk production, production per cow, and a consolidation of dairy farms into larger herds. Concomitant with this growth has been an increasing per capita consumption of fermented dairy products such as cheese, yogurt, and sour cream (Dairy Facts, 2004). The per capita natural (nonprocessed) cheese consumption has risen from just over 17 pounds in 1980 to over 30 pounds in 2004 . Total cheese production rose from 3,984 million pounds from 1980 to 8,598

Received September 6, 2005.

Accepted October 28, 2005.

${ }^{1}$ Corresponding author: Jumbo@cdr.wisc.edu million pounds in 2003. Larger cheese manufacturing plants were and are being built or existing ones expanded not only to meet the demand for fermented dairy products but also to improve production efficiency. The largest plants have capacities that can handle in excess of 8 million pounds of milk per day. The number of USDA-inspected cheese plants has dropped dramatically (from 737 in 1980 to 399 in 2003), particularly those that were producing Cheddar, Swiss, and Mozzarella, the so-called main commodity cheeses. However, the production of Cheddar has increased from 1,751 million pounds in 1980 to 2,749 million pounds in 2003 . Mozzarella showed the most dramatic increase of all cheeses going from 689 million pounds produced in 1980 to 2,806 million pounds in 2003. Indeed for a short time in 2003, Mozzarella was even higher than Cheddar in total pounds of cheese produced. Swiss cheese production increased only by approximately 50 million pounds in the same period. There has been a dramatic shift in cheese production from the Midwest states to the western states, especially California and Idaho. A new cheese production facility was commissioned in 2005 in Clovis, New Mexico, that is planned to process 2.4 billion pounds of milk per year when fully operational. Incorporation of efficient horizontal cutting and stirring vats has become an industry standard for the larger or newer facilities. These vats have capacities of 70,000 pounds of milk vs. the 35,000 to 50,000 pound capacities that were common in the standard sized vats of 25 yr ago.

\section{Process Control}

Along with this increase in production of cheese is the need for better process control. Computer chip technology is being replaced by software-driven computer control systems that have made it easier and faster to change parameters during processing/production cycles. This technology has also resulted in the use of inline standardization of milk for cheese making, a necessity in larger plants for economic and efficient management of resources and better process control for the production of consistent quality cheese. In addition, standardization of the gel strength at cutting to improve cheese yield and moisture control using in-vat sensors (described by O'Callaghan and coworkers) has become 
common practice in large operations. Although open cheese vats are still being used for the entire cheesemaking process, especially in smaller cheese plants, the popular enclosed vertical cutting and stirring vats are now being rapidly replaced by redesigned enclosed horizontal cutting and stirring vats. The reason is most likely due to improvement in cheese yield (less fines and fat loss due to the cutting and subsequent stirring procedures) but the cutting mechanism in horizontal vats also allows the cheese maker to use higher solids milk (concentrated milks) thereby improving productivity. Not surprisingly, the increase in the availability of used vats has resulted in many small plants replacing the open vats with the enclosed vertical cutting vats.

\section{Milk Standardization}

On-farm ultrafiltration of raw milk (either skim or whole milk) is now commercially viable but is practiced in only a few states and is currently limited to a few very large herds. Ultrafiltered whole milk is concentrated to approximately $30 \%$ total solids and ultrafiltered skim milk to approximately $18 \%$ total solids and shipped to cheese makers across the United States for use in standardizing milk or supplementing existing milk supplies to increase manufacturing productivity. Ultrafiltered or microfiltered milks can currently be used for cheeses without a standard of identity, but is being allowed by special permission for Cheddar, Mozzarella, and Swiss cheese as long as its use is put on the ingredient label. Changes to the FDA regulations are currently being discussed that would allow the use of milk concentrated by membrane filtration processes to be used for any cheese.

Before the 1990s, there were few options to standardize milk: remove or add fat as cream, or add casein as nonfat dry milk, evaporated, or condensed milks. Milk was generally standardized to the desired casein to fat ratio or at least to a desired fat level to produce a cheese with the desired solids composition. But there were limitations and certain liabilities associated with adding sources of casein. The lactose content of concentrated milks was over $50 \%$ of the solids. Unless water was added to the concentrated milks (diluted back to the original volume), the lactose content of the serum of standardized milks made with them was higher. Adding water back was defeating one of the reasons to add solids-to increase productivity. Consequently, cheese makers had to make expensive adjustments in the make process or risk manufacturing a cheese with excessive acidity or a cheese that would darken with age or when baked. With the development of more efficient membranes in the 1990s, ultrafiltration of milk became an economically viable option as a standardization tool.
Ultrafiltration partitions milk into an enriched protein and fat fraction and a serum fraction containing both water and lactose (lactose in the serum portion fraction stays the same). Consequently, when the enriched protein and fat fraction is added to milk for standardization purposes, the protein and fat content of the milk increases but the lactose content of the serum phase remains the same. The cheese made from this blended milk avoids the problems associated with excessive lactose. Diafiltration (adding water back to the ultrafiltered milk followed by ultrafiltration again) has been used to standardize milk in regards to fat, casein, and lactose contents. Microfiltration of skimmed milk creates a casein-enriched fraction as well as a serum protein-enriched fraction. Commercially, selected serum proteins are removed from the serum protein fraction by ion-exchange chromatography. In some cases, the proteins that remain are heat denatured and added back to the casein-enriched fraction and the milk is used for cheese making (especially high-moisture cheeses). Consequently, creative membrane processing of milk makes it possible to standardize milks to precise casein, fat, serum protein, and lactose contents. Whether it is an economic viable option for all cheeses remains to be seen.

\section{The Benefits of Microbial Genetics in Cheese Making}

Cheese making in large facilities has, by necessity, become a highly automated, standardized process. However, concomitant with these changes is the necessity of the starter culture system to be consistent and dependable with respect to the rate of acid development. The most costly problem with starters has been slow acid development due to bacteriophage infection. Phenomenal progress has been achieved in this area especially through the work on the genetics of Lactococcus spp. as initially championed by McKay (University of Minnesota) in the 1970s and continued by Klaenhammer (North Carolina State University) and many others specifically on bacteriophage resistance and host defense mechanisms. The number of researchers, and of course progress, in the genetics of lactic acid bacteria has indeed grown exponentially in the last 2 decades.

Another driving force for studying the genetics of lactic acid bacteria has been the desire to control the development of flavor in dairy products. Much of the work in cheese has been (and will continue to be) to first identify specific flavor components, match the flavor component to a specific flavor attribute in cheese, and then to determine the exact chemical and metabolic pathways giving rise to them. Another important realization that has occurred in the last 2 decades is that 
these studies must be conducted under conditions that actually exist in cheese. Specific environmental factors that have been identified include partitioning of reactants and end products between serum and fat phases, water activity, redox potential, and anaerobic vs. aerobic conditions.

Recently, the genomes of selected strains of lactic acid bacteria have been characterized by Klaenhammer (North Carolina State University) and colleagues from around the world. This will facilitate more rapid and definitive work on bacterial metabolism in dairy products, and will undoubtedly lead to better understanding of the growth of lactic acid bacteria in dairy products. Eventually this information will aid in the development of specific adjunct bacteria to manufacture consistent desired flavor in dairy products. The use of adjunct microorganisms, specifically yeasts and lactobacilli strains, has already gained acceptance as the preferred means to introduce specific flavor attributes in a variety of cheeses.

Genetic manipulation of selected bacteria and fungi is also being used to produce animal enzymes that are now routinely used by cheese makers. Fermentationderived chymosin (FDC) was approved for use in cheese making by the FDA in the early 1990s. It was the first enzyme approved for food use by the FDA that used recombinant DNA biotechnology. It was concluded by the FDA that FDC was more pure than traditional calf rennet and was identical to its natural counterpart. It is widely used in the United States and many parts of the world and may have up to $80 \%$ of the global market share for rennet. Barbano and Rasmussen (Cornell University, Ithaca, NY) verified that the yield, texture, and quality of cheese made with FDC was comparable to that made with calf chymosin and that FDC was superior in terms of yield to other coagulants. However, microbial rennets have undergone substantial improvements including reduction in their thermal stability, a particularly important aspect for controlling proteolysis and maintaining curd pliability in Swiss and Mozzarella cheeses, and reduction in nonspecific proteolysis, a key factor for improving cheese yield.

\section{Specialty Cheese}

In contrast to the decrease in the number of cheese plants producing commodity cheeses, there has been a steady increase in the number of cheese plants producing what are (or were) called specialty cheeses; that is, mold-ripened cheese, Havarti, Italian varieties, Gouda, Feta, Latin American, flavored, washed, or smear-ripened cheeses, and lower fat versions of many varieties of cheese. The gray area between what is a specialty or commodity cheese is often blurred; for example,
Cheddar aged several years can be considered a specialty cheese.

There has been considerable improvement in the quality and awareness of US-made artisanal and farmstead cheeses made from the milks of cows, sheep, and goats or blends of these milks in addition to cheeses made from organic milks. These changes have resulted in a large increase in both the number of cheese varieties readily available in the US market and in the number of producers of these cheeses. With this high level of interest, there are a growing number of continuing education courses being offered throughout the country on all aspects of producing the desired cheeses. Several books have been published on cheese in the last $25 \mathrm{yr}$ and the plenary example of these new books, Cheese: Chemistry, Physics, and Microbiology by Fox and coauthors (University College, Cork, Ireland) has already gone into its third edition since 1987 . These books not only exemplify the dramatic increase in cheese-related research but also the desire for comprehensive reviews and interpretation of the research for students and technologists alike.

\section{Cheese Chemistry and Functionality}

Most of the cheese produced in the United States today is either processed or used as an ingredient in other foods. Cheese is now routinely manufactured to meet specific requirements of taste, color, melt, and mouth feel as demanded by the end-use application. Although it was recognized that the performance of cheese in these applications depends on the chemistry of the casein network, which is manipulated by controlling the rate and extent of acid development, it was a paper by Lawrence and coworkers (New Zealand Dairy Research Institute) in 1984 that brought this concept into broader appeal to cheese technologists. Indeed, since this milestone, there has been an explosion of research focusing on the molecular chemistry of casein and how it relates to all characteristics of cheese. Even the holy grail of dairy chemistry, the structure of the casein micelle, has been "remodeled" by Horne (Hannah Research Institute, Scotland) and has been used by Lucey and coauthors (University of Wisconsin) as a basis for explaining the rheological properties of cheese. Concomitant with research on casein chemistry and cheese rheology were advances in standardizing the terminology used to describe physical properties of cheese (IDF, 1991), improving methods to quantify the proportions of soluble and insoluble phases of calcium (Hassan and coworkers, University of Wisconsin), and improvements in functionality testing as described by Guinee and coworkers (Dairy Products Research Center, Teagasc, Moorepark, Ireland). 


\section{Cheese Microbiology and Safety}

Illnesses and even deaths associated with the consumption of cheese contaminated with Listeria monocytogenes galvanized the entire industry from suppliers to end-users and opened up a new vigilance for pathogen testing and awareness of the dairy plant environment as a source of contamination. There are now more rapid and precise methods of identification of several emerging pathogens such as Campylobacter and Escherichia coli $\mathrm{O} 157: \mathrm{H} 7$. The industry has taken a proactive rather than reactive approach and has taken very seriously the establishment as of as-yet voluntary Hazard Analysis and Critical Control Point (HACCP) programs. There is renewed interest and progress in developing bacteriocin-producing starters or adjunct cultures to aid in the inhibition of contaminating bacteria. Use of natamycin to prevent mold growth on the surface of cheese, specifically shredded cheese, has become routine practice

\section{Whey}

Due to economic and environmental pressures, most cheese manufacturing plants must now develop processes to recover all solids of the milk. Three decades ago it was said that someday cheese would become the by-product of producing whey. For some (especially in the large cheese plants), that day has arrived. The major advances in economically processing milk and whey into various components have been in the use of membrane processing, particularly reverse osmosis, ultrafiltration, microfiltration, and ion-exchange technology (IDF, 2004). Of course, hand in hand with new or improved products derived from whey is the enhanced knowledge of their functional properties, which have enabled their incorporation into more food products, including beverages. Membrane processing systems allow the separation of milk and whey components into various fractions. The vision of Maubois (Institute National de la Recherche, Rennes, France) is now a commercially viable technology (Rosenberg, University of California, Davis). It is no longer just about lactose or dried whey; there are now whey protein concentrates with protein contents as high as $89 \%$ and whey protein isolates with over $90 \%$ protein fractions enriched in $\beta$ lactoglobulin or $\alpha$-lactalbumin or isolated components such as glycomacropeptide or lactoferrin. With the proper selection of specific pore sizes and operating pressures it is now possible with microfiltration to create separate protein fractions directly from skim milk before cheese making; one enriched in casein micelles and the other enriched in serum proteins without the rennet by-product glycomacropeptide. Microfiltration is also being used commercially to filter out bacteria, par- ticularly spore formers from whey and milk (especially in Europe for certain types of cheeses to avoid the need for nitrate addition, and in Canada for increasing the shelf life of pasteurized milk).

\section{CONCLUSIONS}

It may be humbling to researchers and technologists, but with all the excellent research on casein chemistry and cheese functionality carried out over the last 25 yr, the key manufacturing principles and protocols to produce the desired cheese and avoid undesirable attributes have remained the same as they have been for many decades; that is, use proper manufacturing practices, use high quality milk of consistent composition from healthy cows that is low in bacterial numbers, make cheese of consistent composition, control the rate and extent of acid development at specific manufacturing steps to produce cheese with the desired physical attributes, prevent contamination of undesirable microorganisms, and avoid temperature and light abuse during storage and distribution.

In the future, the use of genomics and proteomics will play a major role in understanding the dynamic biochemical and microbiological reactions in cheese. There will be greater understanding of the molecular interactions that determine cheese texture and functionality. The types of cheeses that will be required to perform as highly functional food ingredients will continue to increase. Greater process control of composition and textural attributes will be possible and this will facilitate improved consistency of cheese products. A challenge to the cheese industry will be the competition with plant-derived "dairy substitutes". Already we see cheese-like and other "dairy" products being developed that replace milk solids with nondairy ingredients. However, even with this competition there will continue to be a strong demand for "traditional" cheeses.

\section{REFERENCES}

Barbano, D. M., and R. R. Rasmussen. 1992. Cheese yield performance of fermentation-produced chymosin and other milk coagulants. J. Dairy Sci. 75:1-12.

Dairy Facts. 2004. International Dairy Foods Association. Washington, DC.

Fox, P. F., P. L. H. McSweeney, T. M. Cogan, and T. P. Guinee. 2003. Cheese: Chemistry, Physics and Microbiology, 3rd ed. Elsevier, London, UK.

Guinee, T. P., and D. J. O'Callaghan. 1997. The use of a simple empirical method for objective quantification of the stretchability of cheese on cooked pizza pies. J. Food Eng. 31:147-161.

Hassan, A., M. E. Johnson, and J. A. Lucey. 2004. Changes in the proportions of soluble and insoluble calcium during the ripening of Cheddar cheese. J. Dairy Sci. 87:854-862.

International Dairy Federation. 1991. Rheological and Fracture Properties of Cheese. Bull. No. 268. International Dairy Federation, Brussels, Belgium. 
International Dairy Federation. 2004. Advances in Fractionation and Separation: Processes for Novel Dairy Applications. Bull. No. 389. International Dairy Federation, Brussels, Belgium.

Klaenhammer, T., E. Altermann, F. Arigoni, A. Bolotin, F. Breidt, J. Broadbent, R. Cano, S. Chaillou, J. Deutscher, M. Gasson, M. van de Guchte, J. Guzzo, T. Hawkins, P. Hols, R. Hutkins, M. Kleerebezem, J. Kok, O. Kuipers, M. Lubbers, E. Maguin, L. McKay, D. Mills, A. Nauta, R. Overbeek, H. Pel, D. Pridmore, M. Saier, D. van Sinderen, A. Sorokin, J. Steele, D. O’Sullivan, W. de Vos, B. Weimer, M. Zagorec, and R. Siezen. 2002. Discovering lactic acid bacteria by genomics. Antonie Van Leeuwenhoek 82:29-58.
Lawrence, R. C., H. A. Heap, and J. Gilles. 1984. A controlled approach to cheese technology. J. Dairy Sci. 67:1632-1645.

Lucey, J. A., M. E. Johnson, and D. S. Horne. 2003. Perspectives on the basis of the rheology and texture properties of cheese. J. Dairy Sci. 86:2725-2743.

Maubois, J.-L. 1984. Separation, extraction and fractionation of milk protein components. Lait 64:485-495.

O'Callaghan, D. J., C. P. O'Donnell, and F. A. Payne. 2000. On-line sensing techniques for coagulum setting in renneted milks. J. Food Eng. 43:155-165.

Rosenberg, M. 1995. Current and future applications for membrane processes in the dairy industry. Trends Food Sci. Technol. $6: 12-19$. 